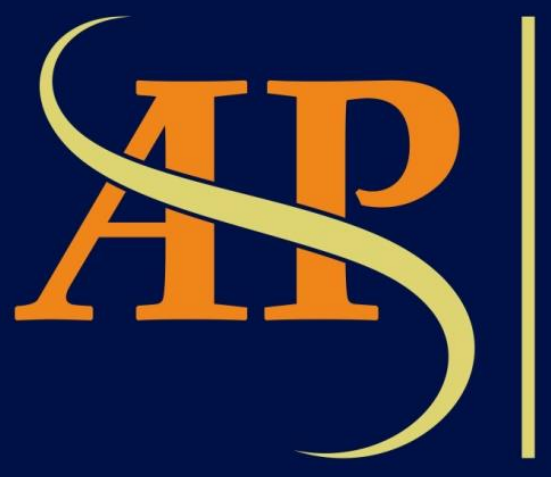

JURNAL ASIA PACIFIC STUDIES

Journal of International Relations Study Program Faculty of Social and Political Sciences Universitas Kristen Indonesia

Volume 4 | Number 1 | January- June 2020 


\title{
PEMBENTUKAN PLA ROCKET FORCE SEBAGAI UPAYA TIONGKOK DALAM PENGAMANAN KEPENTINGAN NASIONAL
}

\author{
Aryo Bimo Prasetyo \\ Magister Ilmu Hubungan Internasional, Fakultas Ilmu Sosial dan Ilmu Politik, \\ Universitas Indonesia, Jl. Prof. Dr. Selo Soemardjan, Depok, Jawa Barat 16424 Indonesia \\ arbims1111@gmail.com
}

\begin{abstract}
President Xi Jinping conducted a military reorganization in 2015. The reorganization included changing the PLA Second Altilery Corps (PLASAC) to the PLA Rocket Force (PLARF) as a new force that was in line with other forces and had the task of handling missile weapons, conventional and nuclear. PLARF is equipped with various missile weaponry. Weapons technology development is carried out to improve the ability of PLARF. Geographically, PLARF is needed to protect China's territorial territory. President Xi Jinping described the PLARF as the core of China's strategic deterrence strength, which was demonstrated through a large military parade. PLARF is also prepared to conduct joint operations, and the CMC's control of PLARF provides unique authority. This article uses offensive-defensive theory in analyzing China's military reorganization. Furthermore, this article will explain why China formed PLARF and prefers to develop these missile weapons through offensive-defensive theory variables. Thus it can be said that the factor of weaponry technology plays a dominant role in the formation of PLARF.
\end{abstract}

Keyword: PLARF, China, Offense-Defense

\begin{abstract}
Abstrak
Presiden Xi Jinping melakukan reorganisasi militer pada tahun 2015. Reorganisasi tersebut diantaranya mengubah PLA Second Altilery Corps (PLASAC) menjadi PLA Rocket Force (PLARF) sebagai matra baru yang sejajar dengan matra liannya serta memiliki tugas untuk menangani persenjataan misil, konvensional maupun nuklir. PLARF dilengkapi persenjataan rudal dengan berbagai jelajah. Pengembangan teknologi persenjataan dilakukan untuk meningkatkan kemampuan PLARF. Secara geografis, PLARF diperlukan untuk melindungi wilayah territorial Tiongkok. Presiden Xi Jinping menggambarkan PLARF sebagai inti kekuatan deterrence strategis Tiongkok, yang diperlihatkan melalui parade militer secara besar. PLARF juga disiapkan untuk melakukan operasi gabungan, serta adanya kontrol CMC terhadap PLARF memberikan kewenangan yang unik .Artikel ini menggunakan teori ofensif-defensif dalam menganalisis reorganisasi militer yang dilakukan Tiongkok. Selanjutnya, artikel ini akan menjelaskan mengapa Tiongkok membentuk PLARF serta lebih memilih mengembangkan persenjataan misil tersebut melalui variabel teori ofensif-defensif. Dengan demikian dapat dikatakan bahwa faktor teknologi persenjataan memegang peran dominan dalam pembentukan PLARF.
\end{abstract}

Kata kunci : PLARF,Tiongkok, Ofensif-Defensif 


\section{Pendahuluan}

Presiden Xi Jinping mulai memimpin Tiongkok pada tahun 2013, Beliau menggantikan posisi Hu Jintao sebagai pemimpin Tiongkok. Posisi yang dilepaskan oleh $\mathrm{Hu}$ Jintao merupakan tiga posisi yang sentral dalam ketatanegaraan Tiongkok, yakni pemimpin negara, pemimpin partai, dan pemimpin militer. Tiga jabatan tersebut memberikan posisi sentral bagi Xi Jinping dalam menentukan berbagai kebijakan negara dalam berbagai tingkatan, artinya kekuasaan sangat besar. Kekuasaan besar tersebut sangat berpengaruh dalam penentuan kebijakan negara yang dipilih oleh pemimpin negara untuk mewujudkan kepentingan nasional. Sejak mengambil alih posisi pimpinan Tiongkok, Xi Jinping telah melakukan berbagai langkah strategis dalam pengambilan kebijakan untuk mencapai kepentingan nasional. Beberapa kebijakan strategis antara lain membentuk Asian Infrastructure Investment Bank (AIIB) sebagai salah satu instrumen ekonomi di tingkat global, kemudian Belt and Road Initiative (BRI), untuk mengembalikan jalur sutra sebagai jalur perdagangan, membentang dari daratan Asia, Eropa hingga Afrika, kemudian dianggap sebagai proyek ambisius oleh berbagai pihak untuk meningkatkan posisi Tiongkok di tingkat global yang berpengaruh tidak hanya untuk perekonomian Tiongkok tetapi juga perekonomian negara lainnya. Keinginan untuk memperkuat perekonomian negara berpengaruh pada sektor lainnya, seperti kebijakan politik dalam negeri maupun luar negeri serta kebijakan pertahanan.

Kebijakan pertahanan yang dipilih oleh negara biasanya dipengaruhi dengan kondisi perekonomiannya, bila kondisi perekonomian negaranya kuat tentunya berpengaruh pada anggaran pertahanan yang besar, semakin besar anggaran pertahanan negara maka dampaknya signifikan bagi kapabilitas militer suatu negara. Hal ini berhubungan dengan proses penelitian maupun pengembangan sumber daya manusia kemampuan alutsista, kemampuan untuk membeli alutsista pertahanan, dan lainnya, tidak terkecuali dengan Tiongkok. Kebijakan ini merupakan bagian untuk mewujudkan kepentingan nasional. Perkembangan teknologi informasi didukung oleh globalisasi memberikan potensi baru dalam pengembangan industri, kepentingan sipil maupun militer. Industri teknologi informasi di Tiongkok berkembang dengan pesat, terutama pada sektor teknologi komunikasi berupa radar, jaringan, maupun alat telekomunikasi. Didorong oleh putaran baru revolusi teknologi dan industri, penerapan teknologi mutakhir seperti kecerdasan buatan (AI), informasi kuantum, big data , cloud, dan Internet of Things memberikan pengaruh di bidang militer (The State Council Information Office of the People's Republic of China 2019).

Presensi Amerika Serikat di Kawasan Asia Pasifik memberikan banyak pengaruh pada modernisasi militer yang dilakukan oleh People Liberation Army (PLA). Amerika Serikat hadir secara langsung melalui armada ketujuh yang beroperasi di Kawasan Asia Pasifik serta didukung pangkalan militer untuk mendukung logistik di Guam. Keberadaan sekutu Amerika Serikat di Asia, seperti Jepang, Korea Selatan, Taiwan, dan Australia turut memberikan pengaruh besar pada Tiongkok untuk mengelola kebijakan pertahanan terkait integritas wilayah teritorialnya. Strategi rebalancing Amerika Serikat serta presensi armada militernya menjadi salah satu ancaman bagi Tiongkok (The State Council Information Office of the People's Republic of China 2015). Amerika Serikat sebagai sumber ancaman bagi Tiongkok dan sekaligus sebagai parameter bagi Tiongkok untuk mengembangkan militernya (Chase, Garafola, \& Beauchamp-Mustafaga 2018). Beberapa parameter Amerika Serikat yang digunakan Tiongkok berada di pembentukan beberapa badan militer, doktrin serta strategi, dan operasi gabungan. Pengembangan militer tersebut walaupun menggunakan parameter Amerika Serikat namun Tiongkok memiliki karakteristik sendiri dalam menciptakan badan militernya sehingga membentuk PLA sebagai militer yang unik.

Pengembangan industri teknologi tersebut berpengaruh pada kebijakan pertahanan Tiongkok, salah satunya adalah kenaikan status badan militer baru yakni People Liberation 
Army Rocket Force (PLARF) menggantikan Second Altilery Corps (SAC), bertugas untuk menangani persenjataan misil, konvensional maupun nuklir. Pembentukan PLARF sendiri merupakan bagian dari reorganisasi militer Xi Jinping pada tahun 2015, di mana perubahan tersebut meliputi perubahan struktur Komisi Militer Pusat (Central Military Commision /CMC), Komando Regional, dan pembentukan People Liberation Army Strategic Support Force (PLASSF). Perubahan organisasi militer tersebut juga memberikan ruang bagi PLARF untuk mengamankan kepentingan nasional Tiongkok di bidang yang sangat dipengaruhi oleh teknologi, terutama teknologi tinggi. Presiden Xi Jinping mendirikan angkatan roket untuk mengambil peran lebih besar dalam pengambilan kebijakan luar negeri (Yang 2018). Perubahan militer tersebut juga dipengaruhi oleh pengembangan teknologi di bidang militer serta pergeseran ancaman terkait dengan integritas teritorial yang dapat mengancam keamanan maupun kepentingan nasional. Hal ini juga mempengaruhi militer dalam mengantisipasi ancaman yang selalu berkembang, selaras dengan adanya perubahan doktrin militer mengenai keinginan Tiongkok untuk memenangkan informatization warfare.

Pembentukan PLARF tersebut merupakan bagian penting dalam reorganisasi militer Tiongkok. Dinamika pergeseran ancaman yang selalu berubah serta presensi negara lain di kawasan Asia Pasifik merupakan ancaman nyata yang dapat mengancam keamanan nasional Tiongkok. Penulis berargumen bahwa pembentukan PLARF tersebut merupakan upaya Tiongkok untuk mengamankan wilayah teritorial Tiongkok sekaligus bersaing dengan negara lain terutama Amerika Serikat. PLARF sendiri merupakan matra militer khas Tiongkok, membedakan PLA dengan militer di negara lain dalam pengembangan bentuk matra. Pengembangan persenjataan misil didukung oleh matra militer yang berdiri sendiri, menimbulkan pertanyaan penelitian yakni mengapa Tiongkok membentuk PLARF untuk mengamankan kepentingan nasional?

\section{Kerangka Pemikiran}

Tulisan ini menggunakan teori ofensif-defensif dalam membahas pembentukan PLARF untuk mengamankan kepentingan nasionalnya. Kepentingan nasional sendiri merupakan kemampuan minimum negara untuk melindungi, dan mempertahankan identitas fisik, politik, dan kultur dari gangguan negara lain (Morgenthau 1951). Pentingnya mengamankan kepentingan nasional berkaitan dengan adanya kemungkinan gangguan bahkan serangan suatu negara terhadap negara lainnya dalam berbagai bidang. Hal ini dapat dikaitkan dengan kondisi survival suatu negara, dimana dalam sistem internasional, negara-negara dalam kondisi anarki. Kondisi tersebut membuat setiap negara memiliki derajat yang sama dengan negara lainnya, sehingga negara tersebut memperkuat berbagai sektor dalam rangka survival. Hal ini juga mengakibatkan setiap negara mengharuskan menolong dirinya sendiri, sehingga setiap negara mengembangkan potensi sektor yang dimilikinya.

Teori ofensif defensif menurut Stephen Evera yang menjelaskan bahwa perang akan lebih mungkin terjadi bila suatu negara memiliki ketimpangan kekuatan yang sangat jauh, dan menjadi pengaruh besar terhadap keseimbangan ofensif-defensif terhadap risiko terjadinya perang. Evera berargumen bahwa kekuatan ofensif yang dominan akan memudahkan penaklukan suatu negara, sedangkan bila kekuatan defensif yang dominan akan menyulitkan penaklukan suatu negara (van Evera 1998). Di dalam teori ofensif-defensif memiliki empat variabel, yakni faktor militer, geografi, sosial-politik dan diplomatik. Pertama, Faktor Militer, terdiri dari tiga bagian yang saling berhubungan, yakni Teknologi militer, doktrin, dan postur kekuatan menjadi faktor berpengaruh pada keseimbangan ofensif-defensif militer, dimana teknologi militer akan menentukan suatu negara akan menjadi agresor atau menjadi defender. Kapabilitas militer suatu negara pada saat ini sangat dipengaruhi oleh teknologi. Hal ini 
berkaitan dengan kapabilitas PLARF dengan teknologi persenjataan yang telah dikembangkan. Kedua, Faktor geografi menentukan penaklukan akan lebih mudah atau sulit bagi suatu negara, ini terkait dengan kontur geografi negara tersebut, apakah mengisolasi negara tersebut dari ancaman negara lain atau tidak. Faktor geografis dapat dikaitkan dengan penempatan posisi markas militer PLARF yang ditempatkan di beberapa wilayah untuk melindungi wilayah geografis Tiongkok

Ketiga, Faktor Sosial-Politik, dimana Rezim yang populer umumnya lebih baik dalam melakukan penaklukan dan bertahan dibandingkan rezim tidak populer. Pemerintah populer dapat melakukan operasi militer di wilayah sendiri maupun di wilayah asing serta pemerintahan yang popular memberikan dampak bagi kekuatan ofensif suatu negara. Ini dapat dikaitkan dengan kebijakan Presiden Xi Jinping dalam membentuk PLARF. Keempat, Faktor Diplomatik, terdapat tiga jenis faktor diplomatik yang memperkuat pertahanan: sistem keamanan kolektif, aliansi pertahanan, dan balancing behavior by neutral states. Ketiganya menghalangi penaklukan dengan mempunyai sekutu dalam melakukan pertahanan. Dalam paper ini, penulis menggunakan tiga faktor pertama yakni faktor militer, faktor geografis, dan faktor sosial-politik dalam menjelaskan pembentukan PLARF sebagai upaya Tiongkok dalam pengamanan kepentingan nasional.

\section{Pembahasan}

\subsection{Faktor Militer}

Modernisasi militer yang dilakukan oleh PLA banyak dipengaruhi oleh militer asing, seperti Amerika Serikat. Keberadaan militer Amerika Serikat di Kawasan Asia Pasifik dengan segala jenis persenjataannya memberikan pengaruh bagi PLA untuk turut melakukan modernisasi, ditambah dengan keberadaan sekutu Amerika Serikat di Kawasan Asia Pasifik juga mempengaruhi PLA dalam melindungi kepentingan nasional Tiongkok di tingkat domestik maupun regional. Kondisi perekonomian Tiongkok turut berperan dalam modernisasi militer, hal ini terkait dengan anggaran pertahanan PLA. Anggaran pertahanan tersebut tentunya dapat dikembangkan untuk melakukan penelitian dan pengembangan, terhadap pengembangan sumber daya manusia, doktrin dan strategi, pengembangan industri pertahanan, hingga pengembangan teknologi persenjataan. Perkembangan teknologi militer yang dimiliki oleh PLA berkembang pesat sejak kepemimpinan Presiden Xi Jinping, menentukan arah perkembangan PLA di tahunmendatang untuk menjadikan PLA sebagai salah satu militer yang sejajar dalam kualitas maupun kuantitas dengan militer dari negara besar lainnya. Mengingat perubahan revolusioner di bidang militer, Tiongkok tidak punya pilihan selain mengubah PLA dari kekuatan yang hanya bermodalkan sumber daya manusia menjadi militer, didukung dengan teknologi, dari kekuatan militer bergantung pada kuantitas menjadi militer berorientasi pada kualitas, yang mana bergantung pada perkembangan ilmu pengetahuan dan teknologi. Tanpa kemajuan teknologi, PLA tidak bisa menjadi kekuatan yang kompeten dan selalu siap untuk pertempuran (Xiangqing 2013). Perkembangan teknologi memberikan pengaruh pada kebijakan pertahanan yang diambil untuk pengembangan postur militer maupun doktrin militer.

Perkembangan teknologi persenjataan, khususnya di bidang roket merupakan salah satu pengembangan persenjataan paling mutakhir, dibuat oleh Tiongkok. Kepemilikan persenjataan roket tersebut akan memberikan efek deterrence terhadap negara lain maupun keunggulan dalam bidang penelitian dan pengembangan. Pengembangan persenjataan roket dapat dikatakan sebagai investasi menguntungkan bagi Tiongkok, tidak hanya menguntungkan dalam melakukan operasi militer bersifat strategis serta melakukan 
perlindungan maksimal terhadap wilayah teritorial Tiongkok, tetapi juga pengembangan roket memberikan keuntungan karena sistem persenjataan tersebut tidak menggunakan awak, sehingga meminimalisir adanya korban dari pihak Tiongkok. Biaya yang dibutuhkan untuk melakukan penelitian dan pengembangan senjata roket tentunya tidak setinggi dibandingkan senjata lain seperti pesawat tempur maupun kapal selam, sehingga dengan memiliki persenjataan tersebut akan lebih menguntungkan dalam pengembangannya. Hasil dari pengembangan persenjataan roket sendiri adalah pada saat ini, Tiongkok dapat menciptakan berbagai macam jenis roket sesuai kebutuhan, dari rudal Surface-to-Air Missile (SAM), Airto-Suface Missile (ASM), Air-to-Air Missile (AAM), Surface-to-Surface Missile (SSM), maupun perlengkapan transportasi penunjang roket tersebut. Kekuatan rudal konvensional Tiongkok termasuk CSS-6 SRBM (kisaran 725-850 km); CSS-7 SRBM (600 km); CSS-11 SRBM (lebih dari $700 \mathrm{~km}$ ); varian serangan darat dan anti-kapal MRBM CSS-5 (sekitar 1.500 $\mathrm{km}$ ); IR-DF-26 (sekitar $4.000 \mathrm{~km}$ ); dan rudal jelajah CJ-10 yang diluncurkan di darat (GLCM) (sekitar $1.500 \mathrm{~km}$ ) (Office of the Secretary of Defense, 2019). Tentunya dengan jarak tersebut memberikan efek deterrence bagi negara-negara yang terdapat dalam jangkauan rudal tersebut, terutama Amerika Serikat. Kemampuan persenjataan yang dimiliki oleh PLARF diharapkan dapat mendukung tugas operasi, pada masa damai maupun perang.

\section{Gambar 1 Kemampuan Rudal Konvensional PLARF}

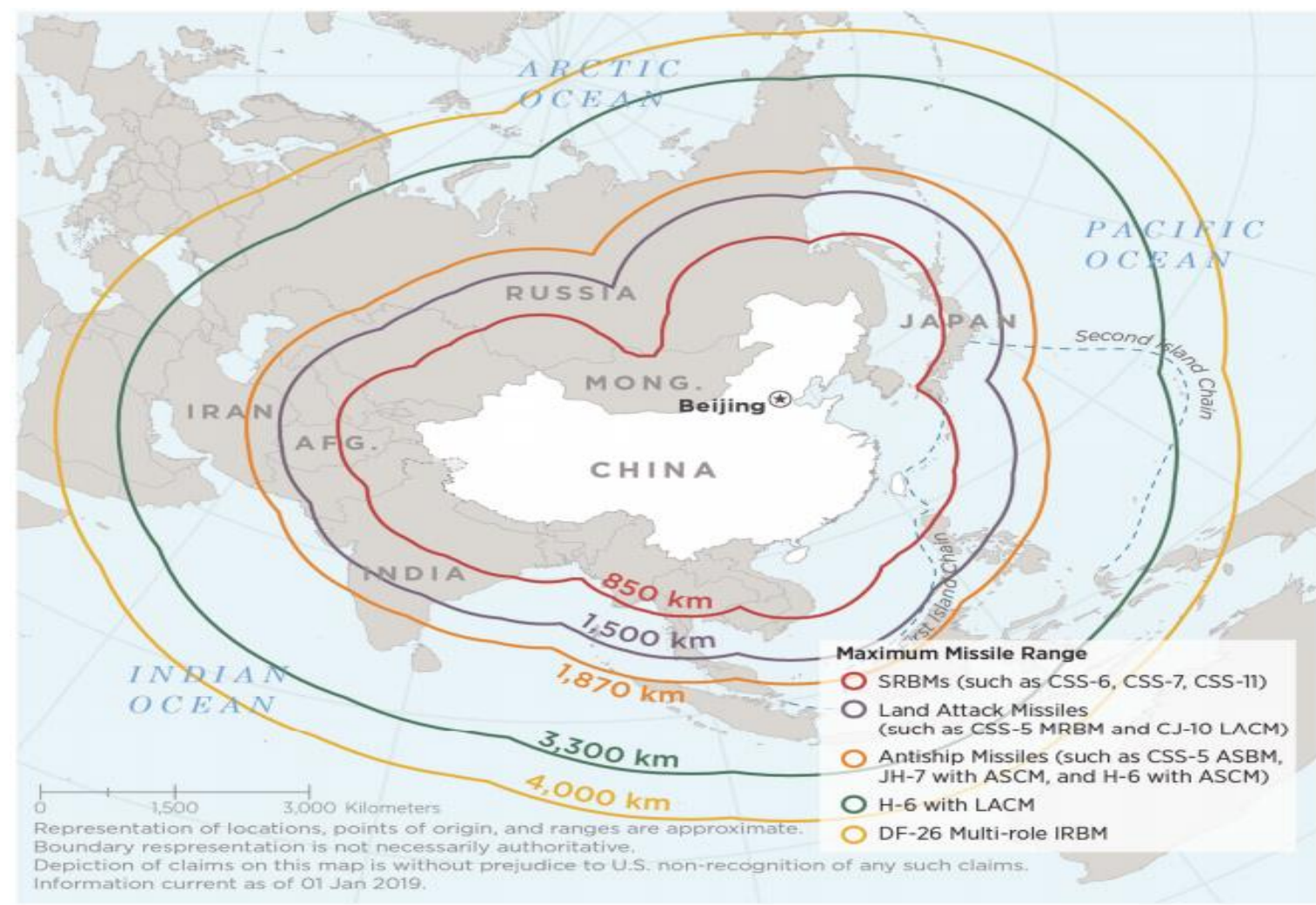

Sumber : Office of the Secretary of Defense 2019

Kemampuan persenjataan rudal Tiongkok, berkemampuan nuklir atau konvensional tentunya sudah berkembang secara pesat, tidak hanya dapat mengembangkan industri pertahanan, tetapi juga melakukan operasi yang menunjang tugas dari PLARF. Kebutuhan pengembangan senjata roket bagi Tiongkok salah satunya adalah untuk mengejar ketertinggalan dalam bidang teknologi militer dengan Amerika Serikat, selain untuk meningkatkan kemampuan persenjataan PLA, dalam kualitas maupun kuantitas serta 
mengamankan wilayah teritorial sekaligus untuk mewujudkan kepentingan nasional. PLARF memainkan peran penting dalam menjaga kedaulatan dan keamanan nasional Tiongkok yang terdiri dari rudal nuklir, rudal konvensional, pasukan pendukung, dan membawahi pangkalan rudal (The State Council Information Office of the People's Republic of China 2019). PLARF memiliki dua misi utama: deterrence strategis dan perang. Sebagai penerus PLASAF, PLARF adalah 'kekuatan inti Tiongkok untuk deterrence strategis' dengan tanggung jawab untuk menghalangi negara-negara lain dari menggunakan senjata nuklir untuk melawan Tiongkok . Peningkatan kapabilitas strategis tersebut dengan memiliki kemampuan nuklir dan konvensional, PLARF harus dapat meningkatkan kemampuan deterrence dan kemampuan serangan balik nuklir, meningkatkan persenjataan yang memiliki presisi dalam jarak menengah serta jarak jauh sehingga dapat membangun kekuatan roket yang kuat dan modern. Peningkatan kapabilitas tersebut tentunya memiliki dampak signifikan dalam pengembangan PLA untuk menjadi militer unggul serta sejajar dengan militer dari negara besar dunia lainnya. Pengembangan teknologi persenjataan menjadi salah satu prioritas yang dilakukan sejak kepemimpinan Presiden Xi Jinping, di karenakan adanya ancaman yang tidak seimbang dengan kemampuan persenjataan PLA. Adanya ketidakseimbangan kapabilitas militer terhadap negara lain dapat menciptakan suatu keadaan yang bersifat asimetris, sehingga perlu diciptakan suatu kondisi mengenai pengembangan alutsista yang dapat memberikan keunggulan terhadap negara lain. Perkembangan teknologi yang berkembang secara cepat dianggap menjadi salah satu kunci dalam mempengaruhi persenjataan secara signifikan, hal ini juga berpengaruh pada saat melakukan operasi militer maupun hasil dari operasi militer tersebut.

Pengembangan kemampuan rudal Tiongkok telah berkembang pesat dalam belasan tahun terakhir, hal ini tidak lepas dengan situasi geopolitik yang berpengaruh besar pada berkembangnya teknologi persenjataan yang digunakan dalam perang. Perang Teluk pada tahun 1990 menunjukkan terjadinya suatu revolusi dalam bidang persenjataan yang diperlihatkan oleh Amerika Serikat terkait kemampuan persenjataan yang presisi, memiliki daya jelajah yang jauh maupun teknologi satelit yang mempengaruhinya. Pengembangan program rudal nuklir yang dikembangkan selama puluhan tahun berpengaruh pada kemampuan teknologi rudal Tiongkok yang jauh lebih maju dibandingkan dengan pengembangan alutsista lainnya seperti pesawat terbang (Gill \& Ni 2019). Pengembangan rudal tersebut berpengaruh pada tugas dari PLARF sendiri, baik nuklir maupun konvensional. Kemampuan ini berpengaruh pada kebijakan pertahanan Tiongkok di kawasan. Tiongkok juga aktif mengejar teknologi hypersonic glide vehicle (HGV), yang dapat dikendalikan, sangat cepat, dan mampu menembus sistem pertahanan rudal yang ada(Gill \& Ni 2019). Tiongkok telah melakukan setidaknya tujuh uji terbang yang sukses dari HGV-nya, yang ditunjuk WU14 (juga dikenal sebagai DF-ZF)(Chen, 2017). Pengembangan HGV dapat dikatakan sebagai persiapan Tiongkok dalam meningkatkan teknologi persenjataan rudalnya sekaligus menempatkan alutsista rudal sebagai senjata utama yang dikembangkan untuk operasi defensif maupun ofensif. Teknologi HGV dipercaya akan menjadi salah satu senjata utama yang digunakan Tiongkok di masa mendatang, HGV sendiri juga dikembangkan oleh Amerika Serikat maupun Rusia. Pengembangan teknologi rudal oleh Tiongkok dapat dianggap sebagai keunggulan secara asimetrik dengan negara lain, di mana negara lain yang memiliki produsen alutsista lebih memprioritaskan pada pengembangan pesawat maupun kapal, sehingga diharapkan pengembangan senjata rudal dapat memberikan Tiongkok keuntungan dalam pengembangan maupun secara operasional. 


\subsection{Faktor Geografis}

Tiongkok merupakan salah satu negara yang memiliki kondisi geografis luas serta berbatasan langsung dengan beberapa negara, dari benua Asia hingga Eropa. Tiongkok berbatasan dengan negara lain di selatan, barat, utara berupa daratan, sedangkan dari arah timur Tiongkok berbatasan langsung dengan Jepang, Korea Selatan, Taiwan, dan Filipina berupa laut. Persinggungan Tiongkok dengan negara dari Kawasan Asia Timur perlu diwaspadai oleh Tiongkok karena beberapa hal, seperti adanya sengketa wilayah dengan Jepang, dan negara tersebut merupakan sekutu Amerika Serikat secara langsung maupun tidak langsung tentunya berpengaruh pada keamanan nasional Tiongkok. Kondisi geopolitik di Kawasan memungkinkan Amerika Serikat untuk terlibat dalam arsitektur keamanan di Kawasan Asia Pasifik, sehingga memungkinkan terjadinya suatu konflik. Keberadaan PLARF sendiri diharapkan dapat meningkatkan pertahanan Tiongkok dalam menjaga wilayah teritorial sekaligus untuk melakukan proyeksi kekuatan di wilayah jauh dari Tiongkok.

\section{Gambar 2 Pangkalan militer PLARF}

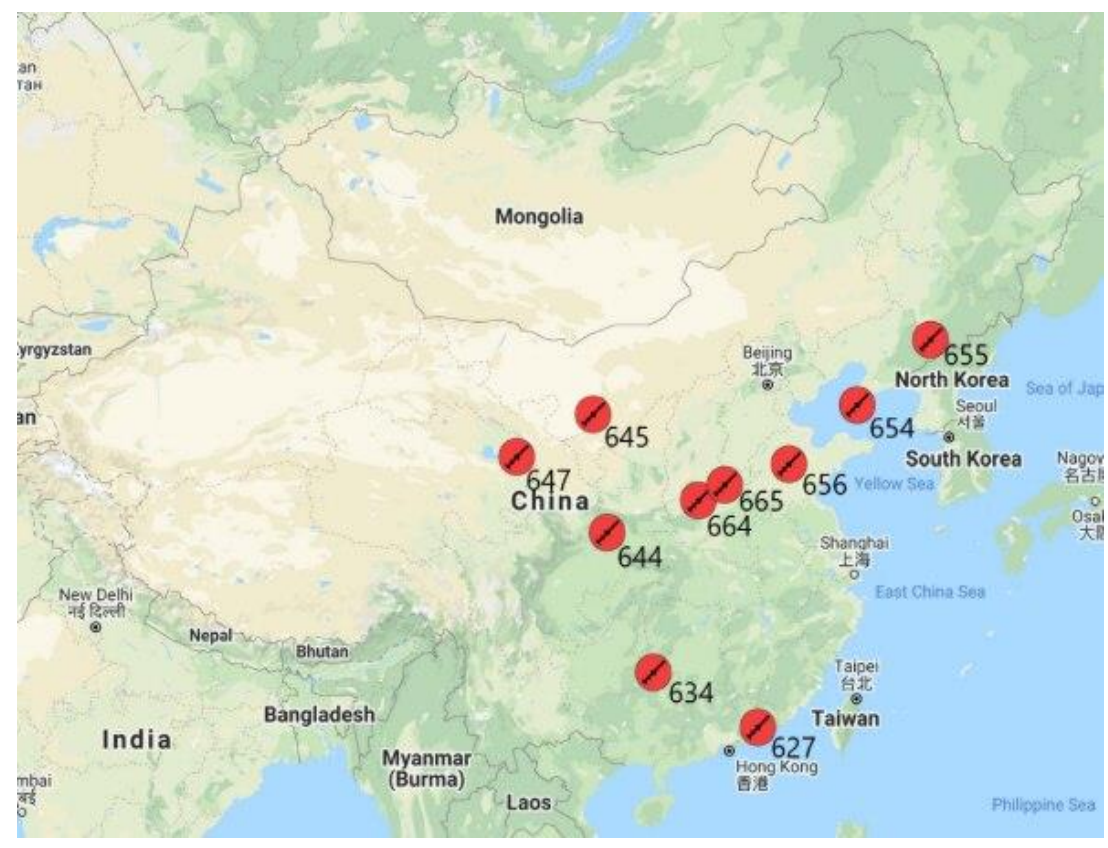

Sumber: Xiu \& Singer 2020

Letak Pangkalan PLARF tersebut tersebar di beberapa wilayah ditempatkan lebih banyak di wilayah timur Tiongkok. Hal ini dapat diindikasikan bahwa kemungkinan ancaman akan lebih banyak muncul dari Kawasan timur Tiongkok walaupun tidak menutup kemungkinan ancaman dari Kawasan barat Tiongkok. Keberadaan Amerika Serikat beserta sekutunya di timur Tiongkok tentu menjadi salah satu alasan penempatan tersebut, selain ditujukan untuk melindungi Beijing dari adanya kemungkinan serangan. Kepemilikan rudal THAAD oleh Korea Selatan dapat dikatakan ancaman bagi Tiongkok, mengingat rudal tersebut dikhawatirkan dapat mengancam keamanan Tiongkok sekaligus mengganggu kestabilan kondisi keamanan di kawasan. Kepemilikan rudal tersebut menyebabkan hubungan kurang baik dengan Korea Selatan maupun Amerika Serikat. Tiongkok menganggap bahwa bantuan terhadap Korea Selatan tersebut tidak hanya untuk memberikan kapabilitas pertahanan terhadap ancaman dari Korea Utara namun juga dianggap akan mengawasi rudalrudal yang diluncurkan dari Tiongkok. Hal ini menjadikan Tiongkok lebih waspada terhadap kemungkinan tersebut sehingga menempatkan pangkalan PLARF di wilayah yang rawan 
terhadap ancaman tersebut. Penempatan pangkalan lain yang ditempatkan di Kawasan selatan Tiongkok, dimana posisi tersebut mendekati Taiwan juga dilakukan untuk melindungi wilayah Kawasan selatan Tiongkok. Setiap pangkalan PLARF serta brigade yang dilengkapi tempat peluncuran bawah tanah, yang digunakan untuk melakukan perakitan rudal. Selain itu PLARF juga dilengkapi dengan truk yang dapat membawa rudal, sehingga peluncuran rudal tersebut dapat dilakukan secara fleksibel.

Keberadaan pangkalan PLARF yang tersebar di beberapa wilayah tersebut, khususnya di wilayah timur Tiongkok dapat membantu strategi anti-access/anti-denial (A2/AD). A2 / $\mathrm{AD}$ adalah upaya untuk membatasi pergerakan musuh di medan perang. Anti-akses -dari gerakan militer musuh ke area operasi - menggunakan pesawat serang, kapal perang, dan rudal balistik dan pelayaran khusus yang dirancang untuk menyerang target utama. Pembatasan Wilayah - pembatasan pergerakan manuver musuh di area yang berada di wilayah sendiri - menggunakan cara yang lebih defensif seperti sistem pertahanan udara dan laut (Krepinevich, Watts, \& Work 2003). Strategi A2/AD ini perlu digunakan untuk melakukan perlindungan terhadap adanya kemungkinan pergerakan militer negara lain sekaligus untuk membatasi pergerakannya. Kapabilitas PLARF sangat krusial untuk bertahan sekaligus melakukan serangan balik, namun perlu adanya dukungan informasi yang akurat dan dukungan sistem persenjataan udara maupun laut. Pembatasan gerak tersebut penting bagi Tiongkok, karena adanya modernisasi alutsista serta perubahan doktrin militer memungkinkan PLA untuk melakukan proyeksi kekuatan di wilayah yang jauh dari perairan Tiongkok. Hal ini penting bagi Tiongkok, agar kemungkinan ancaman yang ada dieliminir ataupun dijauhkan dari daratan Tiongkok. A2 / AD Tiongkok terkonsentrasi di sekitar Taiwan dan Laut Cina Selatan, menempatkan pasukan militer A.S. - seperti Carrier Strike Group dan instalasi di wilayah tersebut dalam jangkauan jelajah berpandu dan rudal balistik. Kemampuan A2 / AD regional ini juga sangat memitigasi kemampuan pasukan A.S. untuk melakukan operasi di Asia-Pasifik. Untuk anti-akses, Tiongkok bergantung pada balistik darat dan rudal jelajah canggih untuk mengancam fasilitas militer A.S. di pulau Okinawa dan Guam (MDAA 2018.) . Kapabilitas PLARF sendiri dapat menjangkau pangkalan-pangkalan militer Amerika Serikat baik di kawasan negara sekutu maupun di wilayahnya, sehingga dapat menekan Amerika Serikat untuk tidak bisa bebas bergerak di wilayah perairan Tiongkok.

Perlindungan terhadap wilayah territorial Tiongkok berkaitan dengan pengembangan teknologi yang mendukung tugas PLARF. Pengembangan teknologi di bidang pengintaian, pengawasan, komunikasi, pelacakan, dan platform sensorik memudahkan PLARF dalam melakukan Tindakan defensif atau ofensif secara presisi. Pengembangan kemampuan nuklir PLARF dapat mempengaruhi hubungan strategis Amerika Serikat dengan Tiongkok, terutama kemampuan serangan balik nuklir. Kemampuan tersebut dapat meningkatkan posisi Tiongkok untuk melakukan deterrence terhadap Amerika Serikat serta aliansi bila terjadi krisis. Kemampauan PLA untuk mengkoordinasi kapabilitas konvensional, nuklir, kemampuan siber dan ruang angkasa akan menyulitkan Amerika Serikat beserta aliansinya dalam melakukan suatu operasi militer. Pengembangan persenjataan rudal, salah satunya HGV dapat membantu Tiongkok untuk melakukan operasi defensif di kawasan terhadap sekutu Amerika Serikat utamanya untuk melakukan perlindungan terhadap wilayah territorialnya secara cepat.

\subsection{Faktor Sosial-Politik}

Faktor sosial politik berkaitan dengan rezim yang diwakili oleh pemimpin negara sebagai representasi dari negara tersebut,dalam hal ini yakni Presiden Xi Jinping. Presiden Xi Jinping memegang tiga posisi pimpinan di Tiongkok yakni pemimpin negara, partai maupun militer yang memberikan kekuasaan sangat besar untuk menentukan berbagai kebijakan negara. Presiden Xi Jinping sendiri sejak mengambil alih seluruh posisi strategis di Tiongkok 
telah memiliki visi besar untuk memajukan Tiongkok serta menempatkan Tiongkok sejajar dengan negara besar lainnya, visi tersebut dinamakan Chinese Dream. Chinese dream merupakan visi untuk mencapai tujuan membangun masyarakat yang makmur dengan segala bentuk, menciptakan negara modern sosialis yang makmur, kuat, demokratis, beradab, dan harmonis, dan mewujudkan impian Tiongkok akan peremajaan besar bangsa Tiongkok, serta mewujudkan kemakmuran negara, peremajaan nasional, dan kebahagiaan rakyat (Zhi 2013). Visi tersebut diharapkan akan menjadi arah pembangunan Tiongkok kedepan dan menjadikan Tiongkok sebagai negara maju, tidak hanya untuk mengembangkan ekonomi, sosial budaya, dan teknologi, tetapi juga untuk pengembangan militer. Inti dari chinese dream adalah peremajaan bangsa Tiongkok, dan suatu bangsa tidak dapat diremajakan tanpa militer yang kuat (Xiangqing 2013). Kekuatan militer suatu negara dilengkapi dengan teknologi yang using akan membuat negara tersebut rentan terhadap ancaman yang dihadapinya, sehingga penting untuk melakukan modernisasi militer.

Presiden Xi Jinping menggambarkan PLARF sebagai, "inti kekuatan deterrence strategis Tiongkok" dan meminta PLARF baru untuk mengembangkan "kemampuan nuklir deterrence dan serangan balasan yang memiliki kemampuan kredibel, andal, dapat digunakan dalam jarak menengah, dan jarak jauh, serta secara berkala memeriksa kapabilitas untuk membangun kekuatan roket modern (Ranade 2017). Keberadaan PLARF dianggap sebagai salah satu hal penting yang telah dilakukan Tiongkok pada reorganisasi militer pada tahun 2015. PLARF sendiri akan dijadikan matra utama PLA dalam melakukan deterrence maupun pengamanan kepentingan nasional, yang pada saat ini kepentingan nasional Tiongkok telah berkembang dari pengembangan dalam negeri menjadi pengembangan berbagai bidang di luar negeri yang membutuhkan keamanan. Tentunya tidak selalu harus menggunakan PLARF untuk melakukan pengamanan, namun PLARF sendiri dirasa penting dalam menjaga keamanan nasional Tiongkok di daratan maupun dalam wilayah proyeksi yang lebih jauh dari daratan Tiongkok. Terkait dengan adanya perubahan situasi di tingkat internasional, serta tantangan pada keamanan nasional keberadaan PLARF akan memainkan peran penting dalam mengendalikan ancaman strategis dan menjaga keseimbangan serta stabilitas di tingkat regional maupun global.

Presiden Xi Jinping memutuskan untuk mengoptimalkan ukuran dan struktur tentara, menyesuaikan dan meningkatkan proporsi antara berbagai pasukan, dan mengurangi institusi dan personel non-tempur, PLA telah memangkas 300.000 personel untuk menjaga total pasukan aktif menjadi dua juta (Hui 2019). Adanya pengurangan jumlah personel tersebut diharapkan PLA dapat dibentuk menjadi militer yang fleksibel, dapat diterjunkan sesuai tujuan operasi militer serta tidak membebani negara dalam hal keuangan maupun kebijakan peningkatan kualitas prajurit. Keberadaan PLARF sebagai matra baru yang sejajar dengan matra lainnya seperti Angkatan darat, laut, dan udara dapat dikatakan mendapat banyak keuntungan dari reorganisasi militer PLA tersebut. Hal ini dapat terjadi dikarenakan Angkatan laut dan angkatan udara kehilangan kendali operasional pasukan mereka ke komando regional, dan Angkatan darat mengalami pengurangan status formal dan kekuatan administratif setelah pembubaran Departemen Staf Umum. Disisi lain, PLARF dapat mempertahankan kontrol langsung dari unit konvensional maupun nuklirnya, serta meningkatkan status organisasi formal dan memperkuat kemampuannya untuk bersaing dengan matra lain dalam hal sumber daya dan melakukan operasi militer (Logan 2016). Keberadaan PLARF menjadi penting dalam agenda Presiden Xi Jinping, pembentukan PLARF didorong oleh dua faktor: pertama, motivasi birokrasi, Kedua, perlunya mengenali peran penting pasukan rudal untuk strategi militer dan keamanan nasional Tiongkok (Ni \& Gill 2018). Pengembangan birokrasi terhadap perubahan SAC menjadi PLARF diperlukan terkait pengembangan organisasi , perubahan doktrin, penambahan anggaran. Perubahan fokus terhadap pengembangan kemampuan serta metode operasi menyertai pengembangan birokrasi 
baru. Keberadaan persenjataan rudal berpengaruh pada sektor doktrin dan operasi, baik dalam tingkat konvensional yang berkaitan dengan skenario di kawasan maupun di tingkat strategis berkaitan dengan kemampuan nuklir yang dimiliki. Sejak Presiden Xi Jinping memimpin Tiongkok, PLARF memainkan peran penting dalam parade kemiliteran yang telah dilakukan beberapa kali. Unjuk kekuatan yang dilakukan termasuk memperlihatkan senjata Dongfeng DF-5 maupun Dongfeng DF-21 yang memiliki kemampuan antarbenua dirancang untuk membawa hulu ledak nuklir dan rudal balistik anti kapal. Parade militer yang dilakukan secara besar dapat diartikan sebagai suatu upaya Presiden Xi Jinping dalam memperlihatkan kemampuan alutsista yang dapat mendukung kepentingan nasional Tiongkok terhadap negara lain, kemudian keberadaan PLARF mendapat peran sentral dalam melindungi keamanan nasional sekaligus kepentingan nasional Tiongkok.

PLARF dalam posisi strategis untuk menjaga kedaulatan dan keamanan nasional, terdapat beberapa kondisi yang melekat, yang dalam perspektif Tiongkok adalah: (a) kepatuhan terhadap penggunaan pertama dan bersifat defensif; (b) tidak ada penggunaan tanpa syarat atau ancaman penggunaan senjata terhadap negara-negara non-senjata nuklir, zona bebas senjata nuklir atau masuk ke dalam perlombaan senjata nuklir dengan negara lain; (c) menjaga kemampuan nuklir pada tingkat minimum yang diperlukan untuk menjaga keamanan nasional (Krishnan 2018). Kebijakan senjata nuklir bersifat no first use dan strategi nuklir bersifat defensif, ini sesuai dengan pernyataan juru bicara pemerintah Yang Yujun bahwa Tiongkok selalu menjaga kemampuan nuklirnya pada tingkat minimum untuk menjaga keamanan nasionalnya (Xinhua 2016). Hal ini juga ditekankan kembali melalui buku putih pertahanannya dan tidak memiliki intensi yang bersifat ofensif terkait dengan segala kebijakan keamanannya. Kebijakan saat ini pada dasarnya untuk menjaga keamanan nasional, mempertahankan kedaulatan negara, integritas teritorial serta reunifikasi nasional, dan mengamankan kepentingan nasional dalam rangka pembangunan ekonomi maupun sosial. Intensi yang ditekankan adalah secara defensif, sehingga tidak ada keinginan Tiongkok untuk melakukan kegiatan ofensif yang dapat merugikan negara lain. Intensi ofensif pada saat ini akan merugikan Tiongkok dalam hal pembangunan ekonomi maupun sosial yang telah dibangun selama beberapa tahun terakhir sekaligus mendukung adanya perdamaian dunia. Seluruh kemampuan PLA, khususnya PLARF terkait dengan reorganisasi militer untuk memberikan rasa aman pada pemerintah terkait dengan kepentingan nasionalnya serta melindungi wilayah Tiongkok dari kemungkinan adanya ancaman terhadap Tiongkok.

Perubahan organisasi ini juga memberikan dorongan untuk teori 'fight and win' Presiden Xi Jinping (Jash 2019). Tujuannya adalah menjadikan PLA sebagai kekuatan militer yang memiliki kemampuan tempur dari seluruh aspek, sehingga dapat menciptakan PLA sebagai militer yang kuat, modern, dilengkapi dengan teknologi yang menunjang, serta efisien dalam melakukan operasi militer agar dapat memenangkan suatu pertempuran. Pengembangan operasi gabungan antar matra di masa yang akan datang mutlak diperlukan untuk mendukung tugas operasi. Koordinasi antara PLARF dengan PLASSF, PLAN, PLAAF, PLAA maupun dengan komando militer regional sangat dibutuhkan untuk mendukung operasi gabungan, salah satunya melalui latihan gabungan yang dilakukan secara terusmenerus. Dalam sebuah laporan 2017 mencatat peningkatan signifikan dalam latihan bersama, melaporkan bahwa PLARF telah meluncurkan ratusan rudal dalam latihan tembakan langsung selama beberapa tahun terakhir untuk meningkatkan kesiapan tempurnya (Logan 2019). Latihan ini perlu dilakukan walaupun pada masa damai, perlu dilakukannya penyiapan pasukan maupun persenjataan, sehingga pada saatnya dibutuhkan, PLARF dapat digerakkan secara langsung. Kontrol erat CMC terhadap PLARF atas sistem rudal konvensional dan nuklir Tiongkok memberikan kemampuan unik untuk menyerang target di luar negeri dan berpotensi memicu konflik (Logan 2019). Sistem terpusat tersebut memberikan dampak negatif terhadap integrasi PLARF dengan komando militer regional saat diperlukan dalam 
melakukan operasi gabungan, dan kemungkinan terjadi insiden atas penilaian buruk terhadap sasaran operasi sangat besar.

\section{Kesimpulan}

Pengembangan matra militer merupakan konsekuensi logis bagi Tiongkok dalam rangka mempersiapkan diri menghadapi berbagai kemungkinan ancaman. Pembentukan PLARF merupakan upaya konkrit Presiden Xi Jinping dalam melaksanakan reorganisasi militer bagi PLA serta untuk membentuk suatu militer yang dapat menjalankan berbagai operasi militer, dalam rangka perlindungan wilayah teritorial, mengembangkan kemampuan second strike capability, dan melakukan proyeksi kekuatan di wilayah yang jauh dari Tiongkok. Kehadiran Amerika Serikat di Kawasan Asia Pasifik menjadi salah satu alasan untuk mengembangkan PLARF agar dapat bersaing dengan Amerika Serikat dalam bidang teknologi persenjataan serta di dukung dengan doktrin dan strategi militer. Keputusan untuk mengembangkan teknologi persenjataan roket sendiri menjadi pilihan tepat bagi Tiongkok dalam mengembangkan industri pertahanannya, tidak hanya biaya pengembangannya lebih rendah dibandingkan dengan pengembangan pesawat tempur. Selain itu persenjataan ini dapat menimbulkan resiko lebih kecil dalam hal kemungkinan adanya korban akibat insiden atau lain halnya. Tiongkok telah dapat menciptakan berbagai macam jenis roket sesuai kebutuhan, dari rudal Surface-to-Air Missile (SAM), Air-to-Suface Missile (ASM), Air-to-Air Missile (AAM), Surface-to-Surface Missile (SSM) Persenjataan roket dapat melakukan deterrence serta dalam peluncurannya dapat diluncurkan secara fleksibel mengingat persenjataan ini dapat diluncurkan di suatu pangkalan tertentu atau melalui kendaraan yang dapat bergerak. Pengembangan teknologi tersebut tentunya akan lebih baik bila di dukung oleh bentuk matra militer yang mendukung teknologi tersebut serta mendapat kontrol lebih atas persenjataan maupun operasi militer. Teknologi persenjataan khususnya rudal dapat menciptakan keunggulan secara asimetrik bagi Tiongkok terhadap negara lain, yang di dukung kemampuan pengembangan dan pembiayaan. Pengembangan senjata HGV menjadi bukti salah satu pengembangan teknologi rudal Tiongkok yang bepengaruh pada masa yang akan datang. Faktor teknologi persenjataan menjadi dominan dalam pengembangan persenjataan maupun organisasi PLARF bersifat strategis.

Secara geografis, Kepemilikan rudal THAAD oleh Korea Selatan dapat dikatakan ancaman bagi Tiongkok, mengingat rudal tersebut dikhawatirkan dapat mengancam keamanan Tiongkok sekaligus mengganggu kestabilan kondisi keamanan di kawasan, sehingga PLARF diharapkan dapat mengemban tugas-tugas strategis terkait dengan strategi A2/AD Tiongkok untuk melindungi wilayah daratan Tiongkok sekaligus memperkecil ruang gerak Amerika Serikat di kawasan Asia Pasifik, dan dapat mengemban tugas dari matra lainnya terhadap PLARF mengenai kendali atas persenjataan roket konvensional maupun nuklir, dilengkapi dengan kendali atas bidang operasional maupun latihan. Pengembangan teknologi dalam bidang pengintaian, pengawasan, komunikasi, pelacakan, dan platform sensorik berpengaruh pada kemampuan defensif untuk melindungi wilayah territorial Tiongkok. Secara sosial-politik, Presiden Xi Jinping sejak mengambil alih seluruh posisi strategis di Tiongkok telah memiliki visi besar yang dinamakan Chinese Dream. Salah satu upaya dalam mencapai visi besar tersebut adalah melalui program penguatan militer yang kuat, baik dari sumber daya ekonomi maupun dalam penelitian dan pengembangan. Presiden Xi Jinping menggambarkan PLARF sebagai inti dari kekuatan deterrence strategis Tiongkok. Parade militer yang dilakukan secara besar dapat diartikan sebagai suatu upaya Presiden Xi Jinping dalam memperlihatkan kemampuan alutsista yang dapat mendukung kepentingan nasional Tiongkok terhadap negara lain, kemudian keberadaan PLARF mendapat peran 
sentral dalam melindungi keamanan nasional sekaligus kepentingan nasional Tiongkok. Keberadaan PLARF menjadi penting dalam agenda Presiden Xi Jinping, pembentukan PLARF didorong oleh dua faktor: pertama, motivasi birokrasi, Kedua, peran pentingnya pasukan rudal untuk strategi militer dan keamanan nasional Tiongkok. Keberadaan PLARF akan memegang peranan penting dalam pengendalian ancaman strategis sekaligus memberikan keseimbangan serta stabilitas di tingkat regional maupun global. Perubahan organisasi ini bertujuan untuk menjadikan PLA sebagai kekuatan militer yang memiliki kemampuan tempur dari seluruh aspek, sehingga dapat menciptakan PLA sebagai militer yang kuat, modern, dilengkapi dengan teknologi yang menunjang, serta efisien dalam melakukan operasi militer agar dapat memenangkan suatu pertempuran. Latihan Bersama dengan matra lainnya telah dilakukan oleh PLARF untuk mendukung operasi gabungan serta melatih kesiapan prajurit bila diterjunkan dalam operasi militer. Kebijakan pertahanan terkait persenjataan nuklir sendiri sifatnya "no first use" dan bersifat defensif sebagai upaya untuk menjaga keamanan nasionalnya. Intensi yang diperlihatkan oleh Tiongkok adalah bersifat negatif dan ditekankan melalui buku putih pertahanan agar negara lain mengetahui bahwa Tiongkok tidak memiliki intensi ofensif yang dapat merugikan negara lain, dan Tiongkok sendiri. 


\section{DAFTAR PUSTAKA}

\section{Buku}

Morgenthau, H. J. 1951. In Defense of the National Interest: A Critical Examination of American Foreign Policy. New York: University Press of America.

Ranade, J. 2017. Xi Jinping's China. New Dehli: KW Publisher.

\section{Dokumen}

The State Council Information Office of the People's Republic of China. 2015. China's Military Strategy.

The State Council Information Office of the People's Republic of China. 2019. China's National Defense in the New Era.

\section{Jurnal/ Artikel}

Chase, M. S., Garafola, C. L., \& Beauchamp-Mustafaga, N. 2018. Chinese perceptions of and responses to us conventional military power. Asian Security, 14(2), 136-154. https://doi.org/10.1080/14799855.2017.1301931

Gill, B., \& Ni, A. 2019. The People's Liberation Army Rocket Force: reshaping China's approach to strategic deterrence. Australian Journal of International Affairs, 73(2), 160-180. https://doi.org/10.1080/10357718.2018.1545831

Jash, Amrita. "PLARF: China's 21st Century Rocket Army." Scholar Warrior Spring 2019, 2019: 72-79.

\section{Laporan}

Office of the Secretary of Defense. 2019. Annual Report to Congress: Military and Security Developments Involving the People's Republic of China 2019.

\section{Website}

Chen, S. 2017. China builds world's fastest wind tunnel to test weapons that could strike US within 14 minutes . Retrieved July 14, 2020, from https://www.scmp.com/news/china/policies-politics/article/2120072/china-buildsworlds-fastest-wind-tunnel-test-weapons

Hui, L. 2019. Reform in China's national defense and armed forces . Retrieved May 5, 2020, from https://news.cgtn.com/news/2019-12-25/Graphics-Reform-in-China-s-nationaldefense-and-armed-forces-MGRXIeWBZm/index.html

Krishnan, A. 2018. The New Red Army: Xi Jinping's Vision for People's Liberation Army. Retrieved from India Today website: https://www.indiatoday.in/magazine/cover-story/

MDAA. 2018. China's Anti-Access Area Denial. Retrieved from https://missiledefenseadvocacy.org/missile-threat-and-proliferation/todays-missilethreat/china-anti-access-area-denial-coming-soon/ 
Ni, A., \& Gill, B. 2018. China's New Missile Force: New Ambitions, New Challenges (Part 1) . Retrieved July 15, 2020, from The Jamestown Foundation website: https://jamestown.org/program/chinas-new-missile-force-new-ambitions-newchallenges-part-1/

Xiangqing, M. 2013. Chinese Dream includes strong PLA. Retrieved May 5, 2020, from https://www.chinadaily.com.cn/opinion/2013-10/08/content_17012886.htm

Xinhua. 2016. China's nuclear policy, strategy consistent. Retrieved from http://english.chinamil.com.cn/news-channels/china-military-news/201601/01/content_6840013.htm

Xiu, M., \& Singer, P. W. 2020. China's missile force is growing at an unprecedented rate. Popular Science. Retrieved from https://www.popsci.com/story/blog-easternarsenal/china-missile-force-growing/

Yang, Z. 2018. Rocket Force gaining power in China's army-dominated PLA. Retrieved from http://www.atimes.com/article/rocket-force-gaining-power-chinas-army-dominatedpla

Zhi, S. Y. 2013. Seven characteristics that distinguish the Chinese dream from the American dream. $\quad$ Retrieved from https://web.archive.org/web/20130520192733/http://www.qstheory.cn/zz/zgtsshzyll/2 01305/t20130520_232259.htm 